\title{
THE INFLUENCE OF UNCERTAINTIES IN THE CALCULATION OF MEAN MONTHLY DISCHARGES ON RESERVOIR STORAGE
}

\author{
DANIEL MARTON, MILOŠ STARÝ, PAVEL MENŠÍK
}

Brno University of Technology, Faculty of Civil Engineering, Institute of Landscape Water Management, Žižkova 17, 66237, Brno, Czech Republic; Mailto: marton.d@fce.vutbr.cz

In normal practice, during the estimation of reservoir storage uncertainties affecting the values of mean monthly discharge series are not normally considered, and usually no estimates of these are known. Therefore, the question arises as to whether the results of the estimation of the capacity of storage reservoirs may be affected by uncertainties in the discharge series. The aim of this article is the suggestion of a possible approach to estimating the level of uncertainties affecting the elements of mean monthly discharge series. These discharge series are subsequently integrated into water reservoir storage capacity calculations, and the significance of the proposed approach is explored.

KEY WORDS: Uncertainty, Monte Carlo Method, Mean Monthly Discharge, Reservoir Storage.

Daniel Marton, Miloš Starý, Pavel Menšík: VLIV NEJISTOT ČLENU゚ REÁLNÝCH PRŮTOKOVÝCH ŘAD NA HODNOTU ZÁSOBNÍHO OBJEMU ÚDOLNÍ NÁDRŽE. J. Hydrol. Hydromech., 59, 2011, 4; 9 lit., 4 obr., 7 tab.

Nejistoty členů řad průměrných měsíčních průtoků nejsou v běžné praxi udávány, není ani znám odhad jejích velikostí. Otázkou rovněž je, zda nejistotami zatížené průtokové řady mohou ovlivnit výsledky vodohospodářského řešení zásobní funkce vodní nádrže. Cílem článku je naznačení možného postupu odhadu míry nejistot zatěžujících členy průtokové řady průměrných měsíčních průtoků a následné začlenění uvedené řady do výpočtů zásobního objemu vodní nádrže a posouzení významu uvedeného postupu.

KLÍČOVÁ SLOVA: nejistoty, Monte Carlo, průměrný měsíční průtok, zásobní objem nádrže.

\section{Introduction}

When managing reservoir capacity it is necessary to have at one's disposal a discharge input series of at least mean monthly discharges processed for an adequately long design period. This flow discharge series gives information about the size and time distribution of water inflow to the reservoir. The values of the average discharges of the required profiles are obtained in different ways over the individual months. When the specific profiles are dealt with one by one, the data is obtained by continuous water stage measurements in discharge profile and with a discharge rating curve. An alternative method is via the conversion of data from another specific profile in the same watercourse or inflow, or via analogy.

During the measurement process in a specific watercourse profile the sampled water stages are affected by a series of minor errors of a random character (most frequently with an hour step). The locations of points in a hydrometric profile which are fitted in a discharge rating curve (as a regression curve) are also affected by these random errors. These errors then enter the statistical processing of repeatedly measured values and measurement uncertainties are determined from them either directly by the calculation of the selective standard deviation of the average as type A uncertainties, or indirectly as B type uncertainties if they are determined in a different way than from repeated measurements. Type B standard uncertainty is obtained using (1)

$u_{B, z}=\frac{\Delta z_{\max }}{\chi}$,

where $\Delta z_{\max }$ is the maximum deviation of the known sources of uncertainty and $\chi$ - the coefficient based on the type of probability distribution, which controls the resource (for normal distribution $\chi=3)$ (Palečar, Vdoleček, Halaj, 2001). 
Measurement uncertainties specify the area in which the measured value can possibly occur around the average of this measured parameter. Type A uncertainties are therefore standard deviations of a selective average termed standard uncertainties $u_{A}$ and they can be geometrical sum with $u_{B}$ to obtain the combined uncertainty $u$. The combined uncertainty $u$ can be multiplied by 2 and 3 to obtain the expanded uncertainties $U b$ and $U a$. All of this can be done provide that the probability distribution of the observed parameter around the average $\mu$ is normal. Interval $\langle\mu-U a ; \mu+U a\rangle$ specifies the area where the observed parameter can occur with probability $99.75 \%$ owing to the influence of error. In this way, an interval where the water stage can occur with high probability is specified at each step of the measurement of the sampled realization of a water stage.

During routine operation it is not possible to repeat measurements and only type B uncertainty is available to those calculating uncertainty during data processing. The above mentioned interval is then determined based on professional experience simply by guessing the measurement uncertainty, or (at best) it is given by the manufacturer of the measuring instrument used. The actual measured value of the observed values is then considered to be an average value.

According to the document (WECC 19/90, 1990), each result obtained by measurement must be accompanied by the size of the uncertainty with which the value is measured. When evaluating the measurement of hydrometric propellers the Czech Hydrometeorological Institute also determines the uncertainty of the water flow through the profile for a specific watercourse. Information on the uncertainty of measuring instruments which is provided by the manufacturer can be used during the determination of the measurement uncertainty of water stages in a specific watercourse profile. It is therefore possible to use that information in attempts to increase the preciseness of the input data that are needed in the water management analysis of reservoirs storage function; i.e., to determine the uncertainty of the individual elements of the real discharge series of mean monthly discharges and find a way to take advantage of this information in the water management analysis of the water reservoir as well as to assess whether this procedure will be of benefit in practice.

\section{Method}

Water stages are measured by a float located at a limnigraph station or by means of pressure probes and bubblers. Each point of the stage-discharge curve (further referred to as the SDC) is obtained for a measuring watercourse profile on the basis of hydrometric measurements and its evaluation in HYDROS software (Starý, 1991-2011), based on standard ČSN EN ISO 748. The points corresponding to the measurements taken are plotted in a $Q, h$ rectangular coordinate system and then they created the empirical points of stage-discharge curve $(Q-$ water discharge through profile, $h$ - water stage). The set of those points is fitted to the empirical stage-discharge curve as a regression curve. The fitting of specific curves was carried out using HYDROM software (Starý, 1995), which allows the SDC to be approximated in the following ways: polynomial, power and combinations of polynomial-polynomial, power-power, polynomial-power and power-polynomial in the event that the SDC is a turning point.

If when fitting to the SDC one considers the uncertainty of input data, i.e. the values of variables that determine the position of a point in the $Q, h$ coordinate system, it is clear that around each point, whose position is determined by the measured data, an area exists in which these points can also independently occur. The intervals of possible occurrence are defined by the chosen normal distribution values of $Q$ and of $h$. If we are considering type B uncertainty (in normal practice we have no choice), then the measured data values of $h$ and corresponding values of $Q$ that are established via the evaluation of hydrometric measurements are considered to be the mean value of the corresponding distribution function. The standard uncertainty $u_{h}$ can be determined via a professional estimate of the largest error with which you can read the stage gauge; this value has to be divided by three. Uncertainty $u_{Q}$ is given directly by HYDROS software during hydrometric measurement. However, it is indicated as type B expanded uncertainty and it is therefore necessary to convert it to standard uncertainty, i.e. it is divided by two.

The random locations of points around measured points determined using the Monte Carlo method. Using the distribution curves of the normal probability distribution and a pseudo-random number generator, a random coordinates of the $(Q, h)$ points for the whole points of SDC was generated. The set of random points was then fitted to the empirical 
SDC. This procedure was repeated according to a selected number of repetitions (further referred to as the NR).

In the case when the sampled realization of a measured water stage at each step of the measurement the above procedure is defined by the probable interval in which the water stage could also occur. If we consider the type B uncertainty of a sampled water stage (in normal practice once again we have no other option), then the mean value of the corresponding normal distribution is considered to be the value of $h$ as measured by a float at the relevant time step of measurement. The standard uncertainty of measurement is in this case given by the manufacturer of the measuring equipment. The analysis procedure is again based on the Monte Carlo method. At each chronological step of the sampling procedure $i$ (for $i=1,2, \ldots, n$, where $n$ is the number of sampling procedures) a random value $h_{i}$ is generated from the surroundings of each measured value $\mu_{i}(h)$. Generated values $h_{i}$ are considered as mutually independent. The generation procedure is indicated in Fig. 1 (Starý, 1984). Each value $\mu_{i}(h)$ corresponds to a distribution curve $F_{i}(h)$, which has a normal probability distribution. Repeatedly randomly generated sequences $h_{i}$ are denoted $N h_{j}$ for $j=1,2, \ldots, N R$ and are termed as random series of sampled water stages.

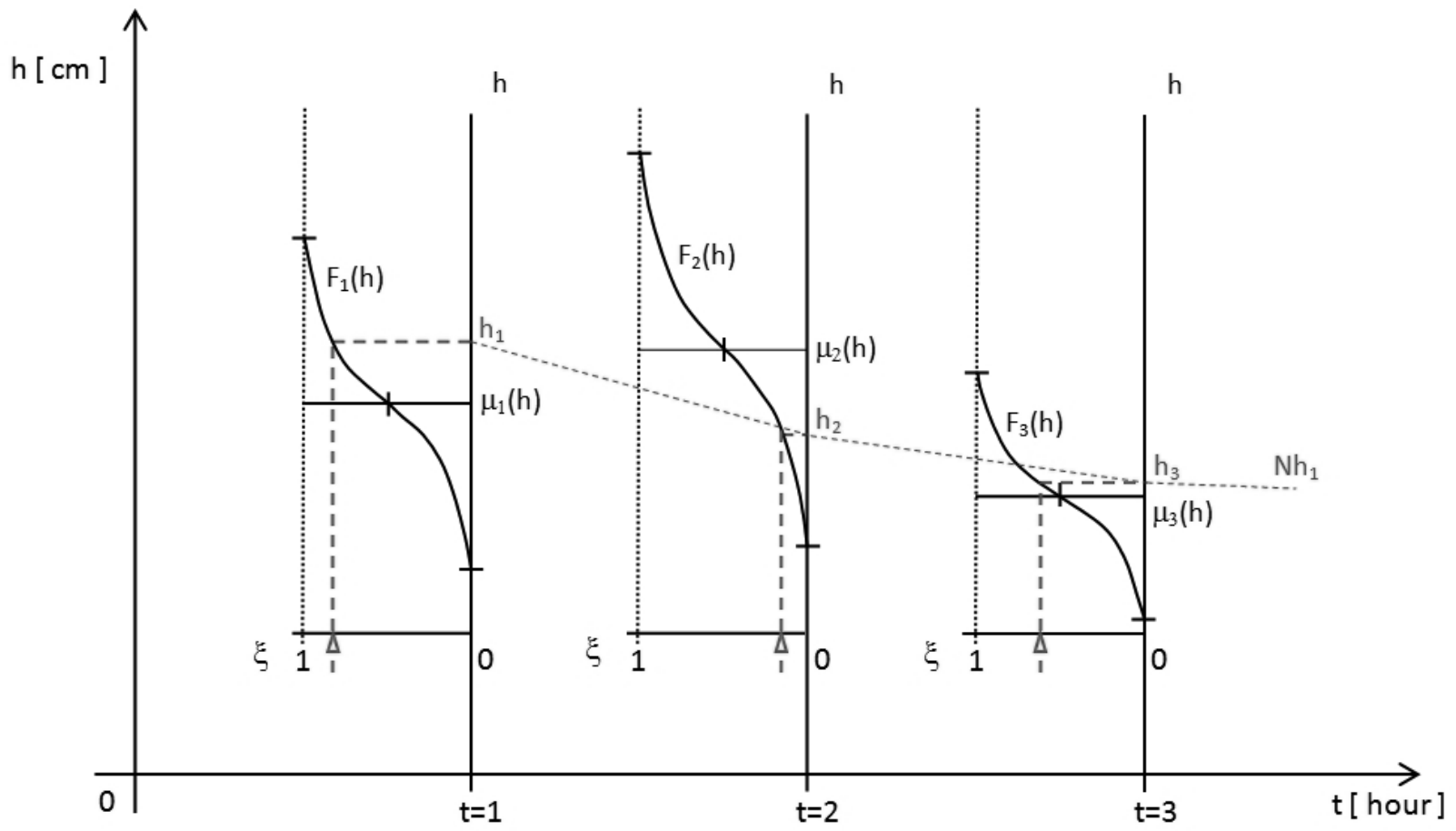

Fig. 1. Scheme of random series $N h_{j}$ generated using the Monte Carlo method.

For the elements of a randomly generated series of water stages $N h_{j}$ the relevant values of the corresponding flows are deducted from the randomly generated SDC sequences. A series of random instant discharges will be established. This series is always processed in relevant month $m$ into the mean monthly discharges $Q_{m}$, where number of mean monthly discharges is corresponding with the period of water stages measuring. The suggested procedure is repeated for the number of repetitions NR.
By this procedure we can to obtain the NR randomly generated mean monthly discharges for every month, which creates a file. Statistical evaluation of the file it is possible to determine the standard uncertainty of the mean monthly discharge in each month.

The random series of mean monthly discharges are then repeatedly utilized in the water management analysis of the capacity of a reservoir storage function. The repeated analysis of the storage capacity functions of a reservoir, where apart from the 
input discharge series there is a requirement for the improved outflow of water from the reservoir and for that improved outflow to be $100 \%$ secured, leads to the calculation of NR storage volumes, which produces a set of NR elements. It is then possible to statistically evaluate that set and assess the impact of the size of input uncertainties on the inputs of the analysis on the values of the basic statistical characteristics of the calculated storage volumes.

\section{Application}

This procedure was applied to determine the uncertainty of mean monthly discharges in three profiles, P1, P2 and P3, which differ in their waterinesses. All profiles are anonymous. The necessary information needed for determination of the uncertainties was obtained from the Czech Hydrometeorological Institute:

- An annual series of sampled water stages measured at a limnigraph station using a float device with a time step of one hour.

- The coordinates $(Q, h)$ of the points obtained by evaluating the hydrometric measurements which are fitted with the SDC.

The standard uncertainties of type B input variables were determined as the following values. The uncertainty for the float measuring device $u_{B, h p}= \pm$ $\pm 0.133 \%$ of the measured value; the uncertainty for the stage gauge $u_{B, h}= \pm 0.166 \mathrm{~cm}$ of the measured value; the uncertainty value for flows obtained by the evaluation of hydrometric measurement $u_{B, Q}= \pm 2.0 \%$. The uncertainty for the LU $503 \mathrm{G}$ float type limnigraph manufactured by NPK Europe Mfg. s.r.o. was obtained from the technical documentation, the uncertainty reading on the stage gauge was determined via professional assessment and the uncertainty of the given flows was determined by subjective generalization of the uncertainty outputs, which are one of the outputs of the HYDROS software according to standard ČSN EN ISO 748. The number of repetitions $N R=100$ was chosen for the Monte Carlo method.

\section{Comment}

It should be noted that in relation to the text in the introduction to this paper that the intervals from which the corresponding random realization inputs are generated are equal to four times or six times those of standard uncertainties.
The individual profiles are sorted by water bearing of watercourse.

Using the following results it is possible to estimate the uncertainties of the mean monthly discharges in profiles $\mathrm{P} 1, \mathrm{P} 2$ and $\mathrm{P} 3$. The information obtained will allow the continued use of uncertainty in calculations of storage reservoir volume.

To obtain the corresponding discharges series we used a simple method of analogy because a sufficiently long series of mean monthly discharges wasn't available in the anonymous profiles. The series of mean monthly discharges Svratka/Borovnice was used as an analogy series. Through the derivation of series using (2), the relevant discharge series corresponding in their hydrometric profile to the profiles P1, P2 and P3 were obtained.

$\frac{Q_{m}^{A}}{Q_{m}^{x}}=\frac{Q_{a}^{A}}{Q_{r}^{X}}$,

for $m=1,2, \ldots, P M$, where $P M$ is the number of months in the analogy series of mean monthly discharges. In the application $P M$ is equal 360. In (2) further indicates $Q_{m}^{A}$ - value of mean monthly discharge from the analogy watershed, $Q_{m}^{X}$ - value of mean monthly discharge from the derived watershed, $Q_{a}^{A}$ - value of long-term average discharge from the analogy watershed, $Q_{r}^{X}-$ value of average annual discharge from the derived watershed. $X$ corresponds to profiles $\mathrm{P} 1, \mathrm{P} 2$ and $\mathrm{P} 3$. Random discharge series $Q_{m}$ were created in a similar way to that described in the previous chapter. The generated random real discharge series were further used as inputs for calculating the storage volume of an insulated reservoir.

The analyzed volume was determined in depend on the defined improved outflow $O_{p}$ and theirs secured $P=100 \%$. Two variants were analyzed. The first variant was solved to derive random discharge series, where the input uncertainty of all elements of the real discharge series are entered as a constant value $u_{Q}$ calculated as a mean from the uncertainties of the mean monthly discharges. The second variant was solved from the series where the input uncertainties $u_{Q}$ were entered individually for each month. The results of solution are shown in Tab. 7 . 
Profile P1 - upper part of the watercourse, $\boldsymbol{Q}_{r}=\mathbf{0 . 3 9 2} \mathrm{m}^{3} \mathrm{~s}^{-1}$

Method of approximation of the SDC: combination of polynomial and power
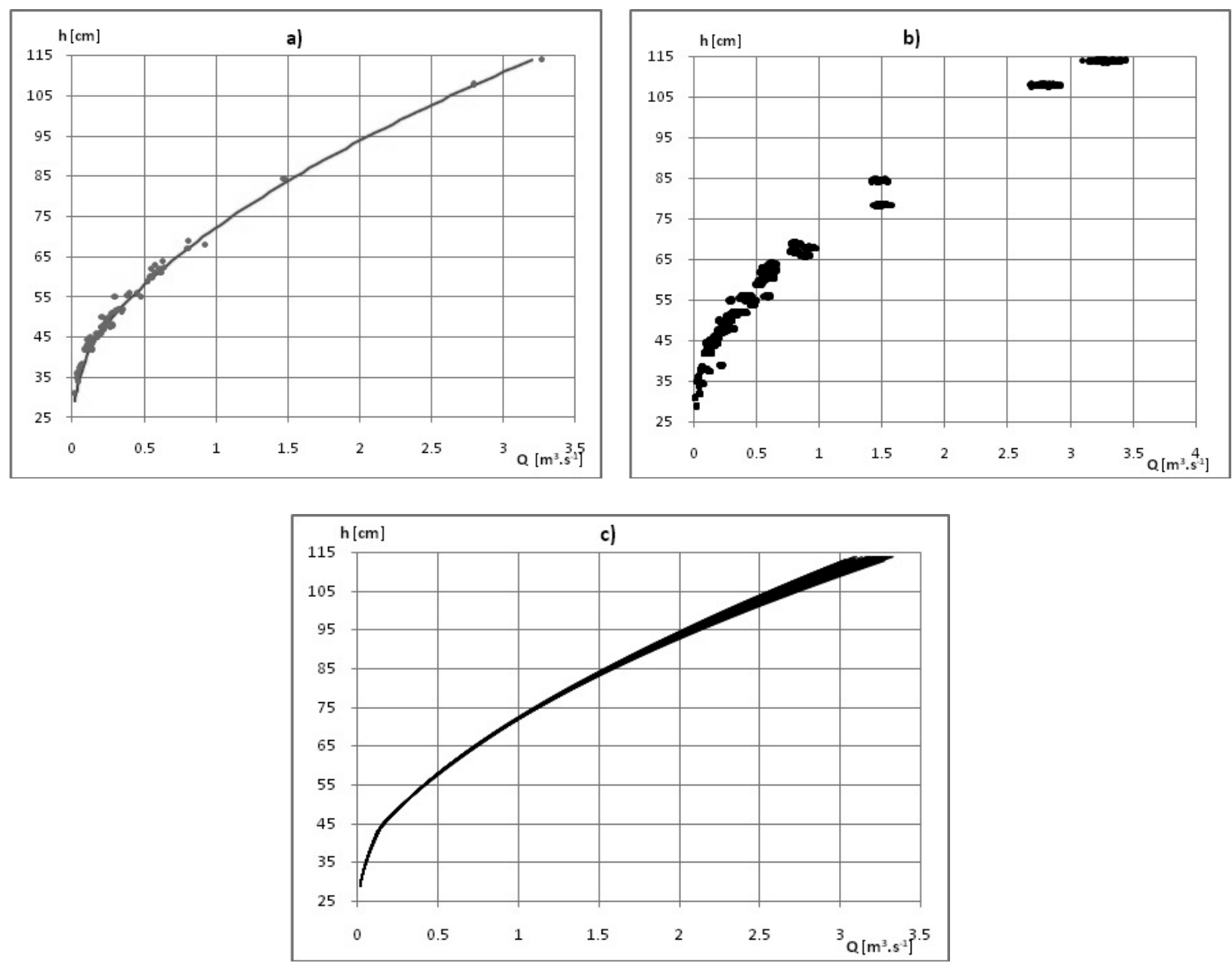

Fig. 2. SDC generated from real measured values and the volume of SDC when considering uncertainty of $(Q, h)$ points in profile P1. On fig. 2. is a) Empirical points of SDC, including the fitted empirical SDC, b) Graph showing the positions of randomly generated $(Q, h)$ points using the Monte Carlo method for repetitions $N R=100$, location of measurement points lies around to the points from graph a), c) Fitted discharge rating curves for the randomly generated points $(Q, h)$ for $N R=100$.

T a b le 1. Mean monthly discharges $Q_{m}$ values derived for the measurement of profile P1.

\begin{tabular}{|c|c|c|c|c|c|c|c|c|c|c|c|c|}
\hline & January & February & March & April & May & June & July & August & eptembc & October & November & December \\
\hline$Q_{m}\left[\mathrm{~m}^{3} \mathrm{~s}^{-1}\right]$ & 0.105 & 0.246 & 0.941 & 0.179 & 0.103 & 0.45 & 1.898 & 0.153 & 0.073 & 0.089 & 0.206 & 0.258 \\
\hline
\end{tabular}

T a b le 2 . The statistical characteristics of mean monthly discharges $Q_{m}$ burdened by measurement uncertainty in profile P1.

\begin{tabular}{|c|c|c|c|c|c|c|c|c|c|c|c|c|}
\hline & January & February & March & April & May & June & July & August & September & October & November & December \\
\hline$\mu\left(Q_{m}\right)\left[\mathrm{m}^{3} \mathrm{~s}^{-1}\right]$ & 0.105 & 0.246 & 0.944 & 0.179 & 0.102 & 0.45 & 1.914 & 0.153 & 0.073 & 0.089 & 0.206 & 0.258 \\
\hline$u_{Q}=\sigma\left(Q_{m}\right)\left[\mathrm{m}^{3} \mathrm{~s}^{-1}\right]$ & 0.0014 & 0.0008 & 0.006 & 0.0007 & 0.0009 & 0.0014 & 0.043 & 0.0005 & 0.0008 & 0.0012 & 0.0021 & 0.0022 \\
\hline$u_{Q}[\%]$ & 1.333 & 0.325 & 0.636 & 0.391 & 0.882 & 0.311 & 2.247 & 0.327 & 1.096 & 1.348 & 1.019 & 0.853 \\
\hline
\end{tabular}

The average $u_{Q}$ value determined from the monthly values is $u_{Q}=0.897 \%$. 
Profile P2 - middle part of the watercourse, $\boldsymbol{Q}_{r}=\mathbf{1 . 8 3 3} \mathrm{m}^{3} \mathrm{~s}^{-1}$

Method of approximation of the SDC: combination of polynomial and power.
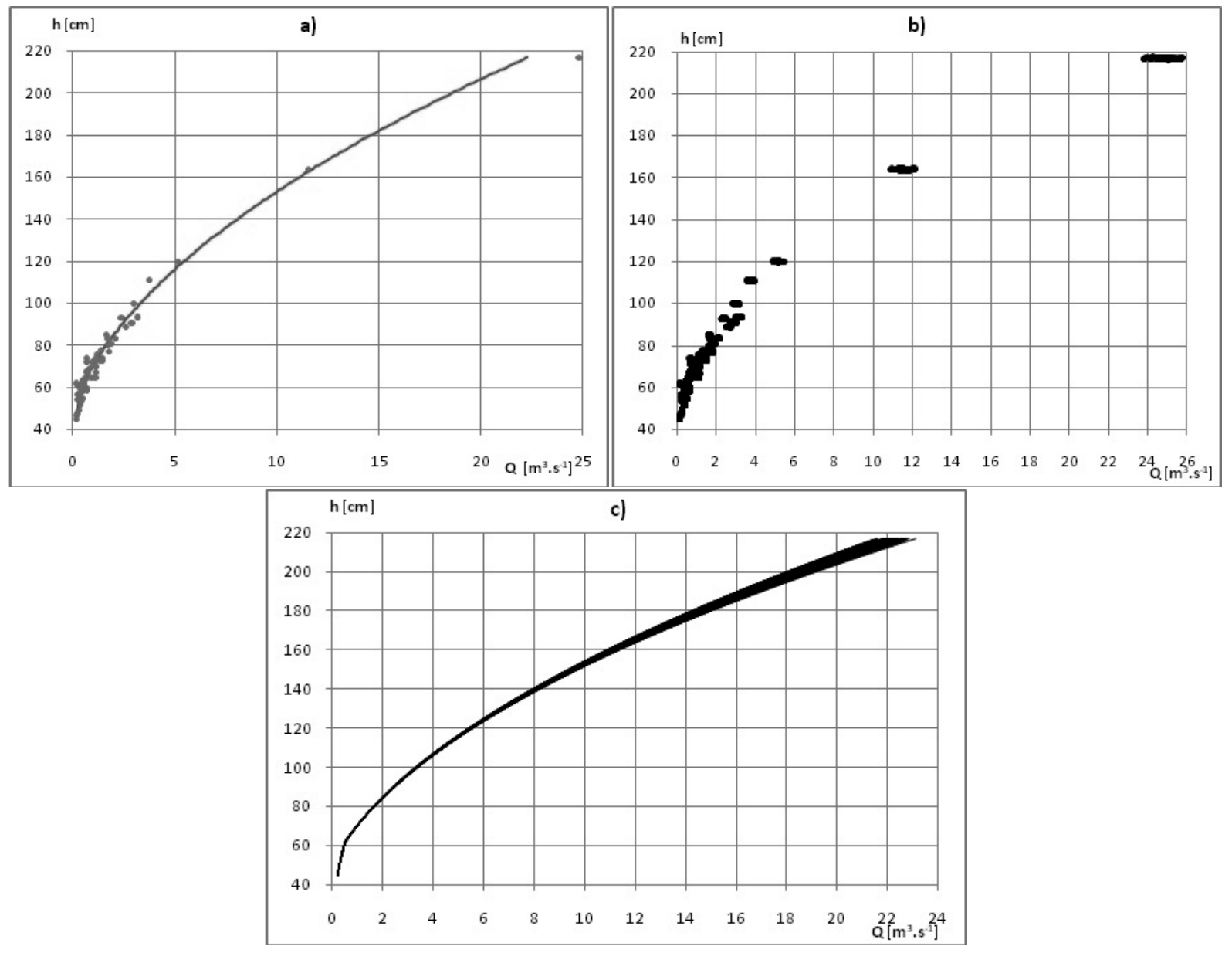

Fig. 3. SDC generated from real measured values and the volume of SDC when considering uncertainty of $(Q, h)$ points in profile P2. On fig. 3. is a) Empirical points of SDC, including the fitted empirical SDC, b) Graph showing the positions of randomly generated $(Q, h)$ points using the Monte Carlo method for repetitions $N R=100$, location of measurement points lies around to the points from graph a), c) Fitted discharge rating curves for the randomly generated points $(Q, h)$ for $N R=100$.

T a b le 3 . Mean monthly discharges $Q_{m}$ values derived for the measurement of profile P2.

\begin{tabular}{|c|c|c|c|c|c|c|c|c|c|c|c|c|}
\hline & January & February & March & April & May & June & July & gust & Sen & Octobe & $\mathrm{Nov}$ & Dec \\
\hline$Q_{m}$ & 1.598 & 1.406 & 6.074 & 3.081 & 0.739 & 1.178 & 2.079 & 0.815 & 0.426 & 1.134 & 1.254 & \\
\hline
\end{tabular}

T a b l e 4. Statistical characteristics of mean monthly discharges $Q_{m}$ burdened by measurement uncertainty in profile P2.

\begin{tabular}{|c|c|c|c|c|c|c|c|c|c|c|c|c|}
\hline & January & February & March & April & May & June & July & August & September & October & November & December \\
\hline$\mu\left(Q_{m}\right)\left[\mathrm{m}^{3} \mathrm{~s}^{-1}\right]$ & 1.6 & 1.407 & 6.087 & 3.087 & 0.737 & 1.178 & 2.082 & 0.813 & 0.426 & 1.136 & 1.254 & 2.218 \\
\hline$u_{Q}=\sigma\left(Q_{m}\right)\left[\mathrm{m}^{3} \mathrm{~s}^{-1}\right]$ & 0.0107 & 0.0066 & 0.0563 & 0.0204 & 0.0048 & 0.004 & 0.011 & 0.0035 & 0.0018 & 0.0054 & 0.0058 & 0.0122 \\
\hline$u_{Q}[\%]$ & 0.669 & 0.469 & 0.925 & 0.661 & 0.651 & 0.340 & 0.528 & 0.431 & 0.423 & 0.475 & 0.463 & 0.550 \\
\hline
\end{tabular}

The average $\mathrm{u}_{\mathrm{Q}}$ value determined from the monthly values is $u_{Q}=0.549 \%$. 
Profile P3 - lower part of the watercourse, $\boldsymbol{Q}_{\boldsymbol{r}}=\mathbf{1 0 . 1 0 9} \mathrm{m}^{3} \mathrm{~s}^{-1}$

The method of approximation of the SDC was by polynomial.
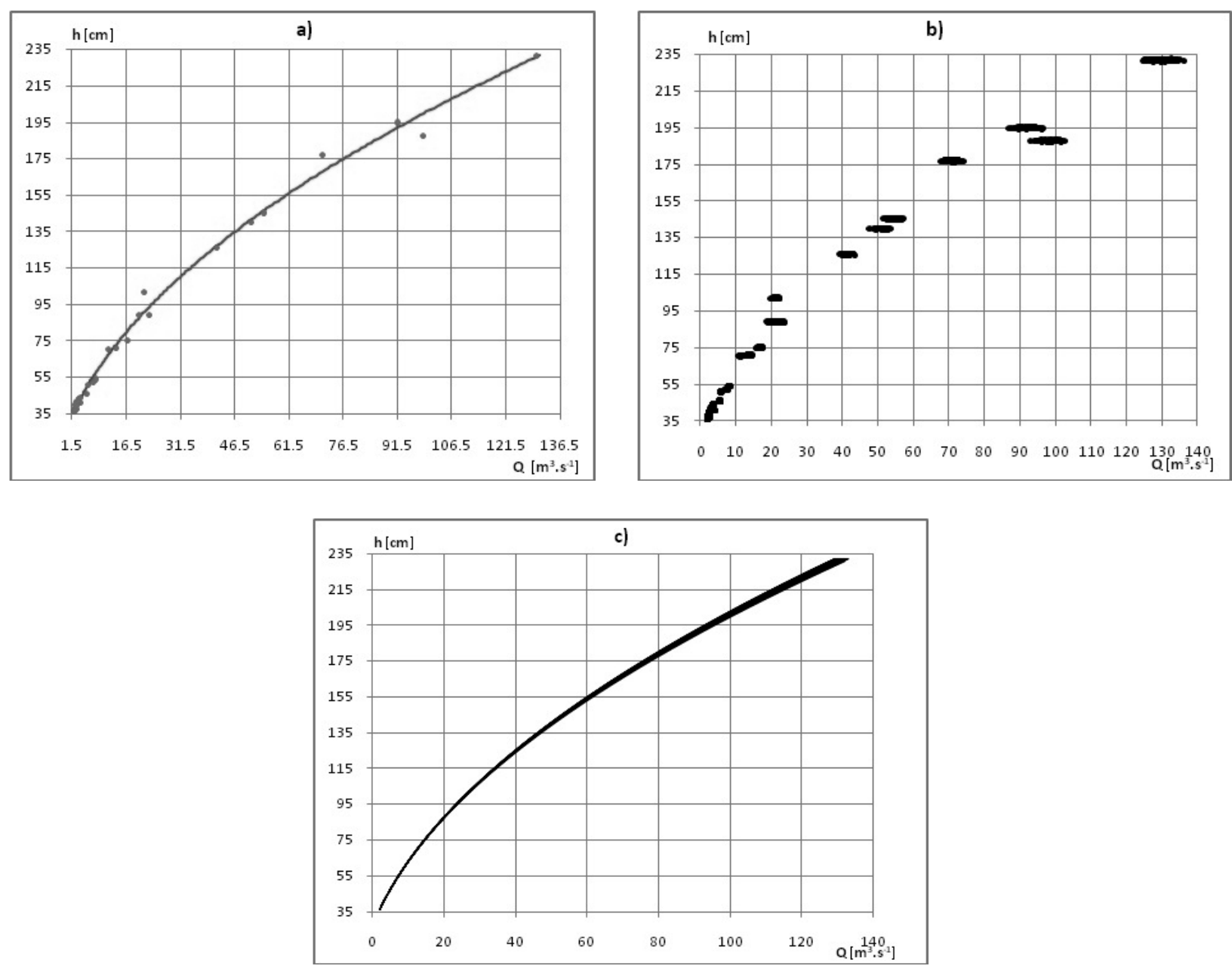

Fig. 4. SDC generated from real measured values and the volume of SDC when considering uncertainty of $(Q, h)$ points in profile P3. On fig. 4. is a) Empirical points of SDC, including the fitted empirical SDC, b) Graph showing the positions of randomly generated $(Q, h)$ points using the Monte Carlo method for repetitions $N R=100$, location of measurement points lies around to the points from graph a), c) Fitted discharge rating curves for the randomly generated points $(Q, h)$ for $N R=100$.

Table 5 . Mean monthly discharges $Q_{m}$ values derived for the measurement of profile P3.

\begin{tabular}{|c|c|c|c|c|c|c|c|c|c|c|c|c|}
\hline & January & February & March & April & May & June & July & August & Septembel & Octobe & November & December \\
\hline$Q_{m}\left[\mathrm{~m}^{3} \mathrm{~s}^{-1}\right]$ & 3.767 & 6.626 & 26.013 & 15.407 & 5.85 & 8.874 & 23.122 & 8.709 & 4.413 & 5.25 & 6.122 & 7.154 \\
\hline
\end{tabular}

T a b le 6. Statistical characteristics of mean monthly discharges $Q_{m}$ burdened by measurement uncertainty in profile P3.

\begin{tabular}{|c|c|c|c|c|c|c|c|c|c|c|c|c|}
\hline & January & February & March & April & May & June & July & August & September & October & November & December \\
\hline$\mu\left(Q_{m}\right)\left[\mathrm{m}^{3} \mathrm{~s}^{-1}\right]$ & 3.766 & 6.628 & 26.023 & 15.4 & 5.85 & 8.88 & 23.123 & 8.709 & 4.413 & 5.251 & 6.124 & 7.156 \\
\hline$u_{Q}=\sigma\left(Q_{m}\right)\left[\mathrm{m}^{3} \mathrm{~s}^{-1}\right]$ & 0.0154 & 0.0276 & 0.1767 & 0.1261 & 0.0252 & 0.0527 & 0.1001 & 0.0437 & 0.0186 & 0.0229 & 0.0281 & 0.0334 \\
\hline$u_{Q}[\%]$ & 0.409 & 0.416 & 0.679 & 0.819 & 0.431 & 0.593 & 0.433 & 0.502 & 0.421 & 0.436 & 0.459 & 0.467 \\
\hline
\end{tabular}

The average $u_{Q}$ value determined from the monthly values is $u_{Q}=0.505 \%$. 
The influence of uncertainties in the calculation of mean monthly discharges on reservoir storage

T a b le 7 . Statistical characteristics of the storage reservoir volume.

\begin{tabular}{|c|c|c|c|c|c|c|}
\hline & \multicolumn{2}{|c|}{ Profile P1 } & \multicolumn{2}{|c|}{ Profile P2 } & \multicolumn{2}{|c|}{ Profile P3 } \\
\hline & constant $u_{Q}$ & $\begin{array}{c}u_{Q} \text { variable } \\
\text { for each month }\end{array}$ & constant $u_{Q}$ & $\begin{array}{c}u_{Q} \text { variable } \\
\text { for each month }\end{array}$ & constant $u_{Q}$ & $\begin{array}{c}u_{Q} \text { variable } \\
\text { for each month }\end{array}$ \\
\hline & \multicolumn{2}{|c|}{$O_{p}=0.314(0.8 \alpha)$} & \multicolumn{2}{|c|}{$O_{p}=1.47(0.8 \alpha)$} & \multicolumn{2}{|c|}{$O_{p}=8.087(0.8 \alpha)$} \\
\hline$\mu\left(V_{z}\right)\left[\mathrm{m}^{3} \mathrm{~s}^{-1}\right]$ & 8830418 & 8830108 & 41438052 & 41435428 & 225160240 & 225192544 \\
\hline$u_{V z}=\sigma\left(V_{z}\right)\left[\mathrm{m}^{3} \mathrm{~s}^{-1}\right]$ & 72516 & 69863 & 207696 & 239190 & 1053040 & 1275314 \\
\hline$U a,_{V z}\left[\mathrm{~m}^{3} \mathrm{~s}^{-1}\right]$ & 217548 & 209589 & 623088 & 717570 & 3159120 & 3825942 \\
\hline$u_{V_{z}}[\%]$ & 0.821 & 0.791 & 0.501 & 0.577 & 0.468 & 0.566 \\
\hline$U a_{, V z}[\%]$ & 2.464 & 2.374 & 1.504 & 1.732 & 1.403 & 1.699 \\
\hline
\end{tabular}

\section{Summary of results and conclusion}

The aim of the article was to outline a possible procedure for estimating the extent of the uncertainty burden on the elements of the discharge series of mean monthly discharges and the subsequent integration of these discharge series in calculations of the storage volume of a water reservoir.

In normal practice uncertainties affecting the elements of mean monthly discharge series are not normally considered, and no estimates of their values are known. It is also not known how the introduction of the uncertainty of the elements of discharge series of mean monthly discharges may influence applications that depend on the use of discharge series of mean monthly discharges as inputs for the analysis. The authors therefore consider the outlined path for calculating the mentioned uncertainties to be original. Also considered original is this method of integrating discharge series whose elements are encumbered with uncertainties into the design of water management systems or into other applications.

From the results presented above it is clear that the uncertainties arising from the initial measurement of water stages and the uncertainty of flows obtained by the evaluation of hydrometric measurements in measuring profiles on a watercourse can influence the resulting solution in dependent applications. With a certain degree of simplification the following conclusions may be formulated:

In profile $P 1$ the value of standard uncertainty is defined as the average for individual months which corresponds to the relative value $u_{Q}= \pm 0.897 \%$ (extended uncertainty $U a,_{Q}=2.69 \%$ ). The introduction of the uncertainty values in the water management calculation was used to determine the storage volume of a reservoir in the profile $\mathrm{P} 1$ with a size of $8.8 \cdot 10^{6} \mathrm{~m}^{3}$ with a possible extended uncertainty of the reservoir volume of $U a,_{V z}= \pm 218000 \mathrm{~m}^{3}$. The result means that the size of the volume may be influenced by $\pm 2.5 \%$.
In profile $P 2$ the value of standard uncertainty is defined as the average for individual months which corresponds to the relative value $u_{Q}= \pm 0.549 \%$ (extended uncertainty $U a,_{Q}=1.65 \%$ ). The introduction of the uncertainty values in the water management calculation was used to determine the storage volume of a reservoir in the profile $\mathrm{P} 2$ with a size of $41 \cdot 10^{6} \mathrm{~m}^{3}$ with a possible extended uncertainty of the reservoir volume of $U a,_{V z}= \pm 623000 \mathrm{~m}^{3}$. The result means that the size of the volume may be influenced by $\pm 1.5 \%$.

In profile $P 3$ the value of standard uncertainty is defined as the average for individual months which corresponds to the relative value $u_{Q}= \pm 0.505 \%$ (extended uncertainty $U a,_{Q}=1.5 \%$ ). The introduction of the uncertainty values in the water management calculation was used to determine the storage volume of a reservoir in the profile $\mathrm{P} 3$ with a size of $255 \cdot 10^{6} \mathrm{~m}^{3}$ with a possible extended uncertainty of the reservoir volume of $U a,_{v z}= \pm 3.2 \cdot 10^{6} \mathrm{~m}^{3}$. The result means that the size of the volume may be influenced by $\pm 1.4 \%$.

When taking into account the impact on uncertainties of elements of the input discharges series separately for each month (variable) is calculated uncertainties resulting from storage volumes in all cases slightly different. In profile P1 decreased uncertainty. The profiles P2 and P3 increased uncertainty.

The obtained results indicate that the impact of uncertainties affecting the elements of the real discharge series on the obtained values for a storage volume is significant. Thus, as individual inputs to a Monte Carlo analysis are introduced by a spectrum of randomly generated input data rather than by a single value, so a calculated storage volume is described as spectrum of storage volumes whose dispersion is significant (for low hydrometric profile a relatively higher dispersion appeared than for higher hydrometric profile). When we realize that the currently used hydrological reliability of designs (the secure of the improved outflow of water 
from the reservoir) according to recommended standards deal with the following values: $99.5 \%$ class A, $98.5 \%$ - class B, $97.5 \%$ - class C and $95 \%$ - Class D (according to the importance of the water users for society), it is clear that the outlined procedure is strongly deformed by the hydrological reliability solutions that are actually achieved. It would be possible to avoid this problem when dealing with the spectrum of storage volumes by considering the maximum storage volume corresponding to the uncertainty $U a,{ }_{V}$, i.e. the value $\mu\left(V_{z}\right)+$ $+U a, V z$ would be considered. An exact solution would of course be to introduce the uncertainties of primary inputs directly into the analysis and to deal with the different types of problems connected with the water management analysis of the storage function of reservoir when considering the secure of analysis using the outlined procedure. The question then remains as to which of these methods is better in practice. In both cases it is necessary to know the uncertainty of the elements of the input discharge series.

Depending on requirements, the uncertainty of the elements of the input discharge series can be dealt with on a case-by-case basis via the procedure outlined in this article. However, there is an alternative, which is to determine the uncertainty of the elements of discharge series before extensive research is carried out on selected profiles of watercourses (different types of watercourses with different hydrometric profile). The results obtained are then evaluated and generalized, and then assigned in a fixed manner to the monthly average discharges corresponding to discharge series evaluated for other specific profiles of various watercourses.

When water management solving of storage function of reservoirs with multiannual control runoff is necessary considered the possibility to correct the values of the elements of real discharge series of mean monthly discharges even in watercourses whose reliability is currently considered to be Class I or II. This correction is not performed for them.

These results were obtained for hydrometric profiles on which hypothetical continuous measurements of water stages were carried out using float gauges and measurements of the point velocity of water flow in specific profiles were also hypothetically performed using hydrometric propellers. The suggested method is universal and can be used for all types of utilized measuring equipment (pressure sensors, bubblers, ADCP, etc.).
The authors foresee the publication of articles, in which will be described the relation to the mentioned problems associated with the determination the size of uncertainty of members of the real discharge series on the basis of other applications. The effect of this procedure into the process of generation of artificial discharge series of mean monthly discharges it will be described as first. The impact of the uncertainty of the elements of real discharge series on the water management analysis of storage functions of a system of reservoirs will be next.

Acknowledgements. The article is the result of specific research FAST-J-10-19 "Design reservoir storages cooperating in the water management systems with consideration of influence uncertainties of elements discharge input series" and the result obtained for the financial support of the Ministry of Education, Youth and Sport's of the Czech Republic, project No. 1M0579.

\section{List of symbols}

$F_{i}(h) \quad-$ normal distribution function,

$h \quad-$ height of water in watercourse [cm],

$N h_{j} \quad-$ random generated sequences of watercourse water height,

$O_{p} \quad-\quad$ affected discharge from reservoir $\left[\mathrm{m}^{3} \mathrm{~s}^{-1}\right]$,

$P \quad-$ secure of affected outflow from reservoir [\%],

$N R \quad-$ number of repetitions,

$Q \quad-$ discharge of water $\left[\mathrm{m}^{3} \mathrm{~s}^{-1}\right]$,

$Q_{m} \quad-$ mean monthly discharge of water $\left[\mathrm{m}^{3} \mathrm{~s}^{-1}\right]$,

$Q_{r} \quad-$ annual discharge of water $\left[\mathrm{m}^{3} \mathrm{~s}^{-1}\right]$,

$Q_{a}^{A} \quad-$ long-term average discharge of water from the analogy watershed $\left[\mathrm{m}^{3} \mathrm{~s}^{-1}\right]$,

$Q_{m}^{A} \quad-\quad$ of mean monthly discharge of water from the analogy watershed $\left[\mathrm{m}^{3} \mathrm{~s}^{-1}\right]$,

$Q_{m}^{X} \quad-$ mean monthly discharge of water from the derived watershed $\left[\mathrm{m}^{3} \mathrm{~s}^{-1}\right]$,

$Q_{r}^{X} \quad-$ average annual discharge of water from the derived watershed $\left[\mathrm{m}^{3} \mathrm{~s}^{-1}\right]$,

$Q, h \quad$ - rectangular coordinate system with horizontal axis $Q$ and vertical axis $h$,

$(Q, h)-$ position of a point in a coordinate system $Q, h$,

$u_{B, z} \quad-$ standard uncertainty type B,

$u_{B, h} \quad-$ standard uncertainty type $\mathrm{B}$ of water height on the stage gauge $[\mathrm{cm}]$,

$u_{B, h p} \quad-$ standard uncertainty type B from the float [\%],

$u_{B, Q} \quad-$ standard uncertainty type B for the discharge obtained by hydrometric measurement [\%],

$u_{Q} \quad-$ standard uncertainty for the discharge, relative [\%], absolute $\left[\mathrm{m}^{3} \mathrm{~s}^{-1}\right]$,

$u_{V z} \quad-$ standard uncertainty for reservoir storage volume, relative [\%], absolute $\left[\mathrm{m}^{3} \mathrm{~s}^{-1}\right]$,

$U a \quad-$ extend uncertainty for $k=3$,

$U b \quad-$ extend uncertainty for $k=2$,

$U a,_{Q}-$ extend uncertainty of monthly discharge, relative $[\%]$, absolute $\left[\mathrm{m}^{3} \mathrm{~s}^{-1}\right]$, 
$U a,_{Q}$ - extend uncertainty of reservoir storage volume, relative $[\%]$, absolute $\left[\mathrm{m}^{3}\right]$,

$V_{z} \quad-$ reservoir storage volume $\left[\mathrm{m}^{3}\right]$,

$\Delta z_{\max }-$ maximum deviation of the known sources of uncertainty,

a $\quad-$ coefficient of affected discharge,

$\chi \quad-$ coefficient based on the probability distribution,

$\mu \quad-$ mean,

$\mu_{i}(h) \quad-$ mean of watercourse water height [cm],

$\mu\left(Q_{m}\right)-$ mean of monthly discharge of water $\left[\mathrm{m}^{3} \mathrm{~s}^{-1}\right]$,

$\mu\left(V_{z}\right)$ - mean of reservoir storage volume $\left[\mathrm{m}^{3}\right]$,

$\sigma\left(Q_{m}\right)$ - standard deviation of monthly discharge of water $\left[\mathrm{m}^{3} \mathrm{~s}^{-1}\right]$

$\sigma\left(V_{z}\right)$ - standard deviation of reservoir storage volume $\left[\mathrm{m}^{3}\right]$,

$\xi \quad-\quad$ standard random variable from interval $<0,1>$.

\section{REFERENCES}

ČSN EN ISO 748 - Hydrometrie - Měření průtoku kapalin v otevřených korytech - metody rychlostního pole. Český normalizační institut, 2001.

Expression of the Uncertainty in Measurement in Calibration. (Metodika vyjadřování nejistot při kalibracích.) EA 4/02, 1997 (v ČR ALE-R2, 1997).
Guide to the Expression of Uncertainty in Measurement (Směrnice pro vyjadřování nejistoty při měření), BIPM, IEC, IFCC, ISO, IUPAC, IUPAP, OIML, 1993.

NPK EUROPE Mfg. s.r.o. UHŘÍNOV, http://www.npke.cz/

PALENČÁR R., VDOLEČEK F., HALAJ M., 2001: Nejistoty v měření I: vyjadřování nejistot. Automa, číslo 7-8, ročník 2001, dostupné na http://www.odbornecasopisy.cz/.

STARÝ M., 1991-2011: HYDROS, Aplikační software určený pro vyhodnocování hydrometrických měření, Brno, 1991$-2011$.

STARÝ M., 2005: HYDROM, Aplikační software určený pro prokládání měrných křivek. Brno, 2005.

STARÝ M., 2005: Hydrologie - Studijní opory pro studijní programy s kombinovanou formou studia. Brno, 2005.

WECC doc. 19 - 1990: Western European Calibration Cooperation, 1990.

STARÝ M., 1984: Zpráva o výsledcích řešení při spolupráci na normalizačním rozborovém úkolu HDP VH 83/6 RỦ. Brno, 1984.

Received 6 April 2011

Accepted 19 October 2011 